\title{
Egy Árpád-kori veremház rekonstrukciója
}

\author{
ZAY ORSOLYA \\ Magyar Nemzeti Múzeum, Közművelődési Osztály \\ H-1088 Budapest, Múzeum krt. 14-16., capitulare@gmail.com
}

Zay, O.: A reconstruction of a pit-dwelling from the era of the Arpad Dynasty

Abstract: In 2010 a group of historical reenactors decided to build a house-reconstruction in Hungary from the 11th-13th centuries. We took part some historical festivals in Europe where the organizers showed high quality experimental archeology to the tourists. We chose a Historical Park in Hungary and got a place where we started the building operations. Informations from archeological and ethnographical articles and monographies were collected after that we search people who have experiences in this theme. After collecting the informations about the houses we planned our building. The group made written notes and photos during the experiment. We only worked in weekends, so that we finished the main procession in 2012. We didn't want to exactly follow or contradict to anybody, only made our idea but persisted in archeological remains.

Keywords: 11 th-13th centuries, building, reconstruction, wooden raw materials, experimental archeology, pit-house

\section{A házépítés előzményei}

A ház felépítésének ötlete 2010 augusztusában született, amikor az építők mind részt vettek egy úton, melynek célja a lengyelországi Wolin és annak régészeti parkja volt. Az ott tapasztalt szakmai pontosság, a felépített épületek, valamint a bennük tartózkodó kézmúvesek, szakemberek munkája - amelyen keresztül bemutatták a közönségnek a korszak szokásait, életmódját - elgondolkodtatott minket. Úgy gondoltuk, hogy egy hazai, saját anyagi kultúránkat bemutató létesítményben, mely könnyen elérhető a magunk és a nagyközönség számára is, készíthetnénk legalább egy házat.

Az alapgondolat az volt, hogy egy olyan házat akarunk építeni, amely a régészeti forrásoknak, a kevés rendelkezésre álló történeti adatnak és a néprajzi párhuzamoknak is megfelel, de mindenképpen lakható, mivel az építőcsapat tagjai hosszabb-rövidebb idő eltöltését tervezték a házban, mind a négy évszakban, annak elkészülése után. Így lett igazán kísérleti jellegű a házépítés, mivel a régészeti nyomok után elképzelt ötleteket, rekonstrukciókat próbáltuk meg eredeti méretben kivitelezni. Eddig nem sok ilyen ház épült, így megpróbáltuk az azokat feldolgozó cikkeket és a korszakkal foglalkozó szakembereket felkeresni, hogy minél több ötletet gyüjthessünk a megvalósításhoz.

A helyszín ma az Emese Várispánság nevet viseli, korábban katonai terület volt (11/12 légvédelmi rakéta osztály Nyeva MN6367, Szigethalom), melyet 2005-től az Őskultúra Alapítvány vett bérbe a szigethalmi önkormányzattól. Pályázva az Európai Regionális Fejlesztési Alap turisztikai kírásaira sikerült az évek folyamán egy 10-11. századi ispánsági központot és az azt körülvevő különböző funkciójú épületeket, épületegyütteseket kialakítani. Saját rendezvényeiken kívül régészeti témájú eseményeknek is helyet ad a park, így 2010 októberében, a Népvándorláskor Fiatal Kutatóinak Konferenciáján, a kísérleti régészeti tárgyú előadások a parkban kaptak helyet. Mivel a park vezetőségének célja a korszak korhű bemutatása, szakemberek bevonásával, kísérleti régészeti módszerekkel, úgy döntöttünk 2010 őszén, hogy egy kisebb területet kérünk az Alapítványtól, egy 10-13. századi lakóépület elkészítésére. Mivel a konferencián nagyon sok, a témában érintett kutató és érdeklődő vett részt, megmutattuk a helyszínt és addig felmerült ötleteinket, ami kifejezetten kedvező fogadtatásra talált a résztvevők körében.

A kivitelező csapat tagjai sokféle területet, szakmát képviselnek. Van köztünk ötvös-fegyverkovács, gépészmérnök, közgazdász, szobafestő, állami apparátusban dolgozó és régészhallgató is. Mivel mind más felkészültséggel kezdtünk neki a munkának, először is egy kutatómunka előzte meg a tervezést. E dolgozat írójára hárult a feladat, hogy a többi résztvevő számára egy érthető, átlátható képet mutasson az egybegyűjtött és feldolgozott kurrens szakirodalom alapján. Miután mindannyian elolvastuk a lehető legtöbb kapcsolódó régészeti, történeti és néprajzi tárgyú közlést a választásunk egy veremházra esett. Próbáltunk minél több szakemberrel értekezni a választás és a kivitelezés kapcsán. Fontos szempont volt, hogy az Árpád-kori falvak kutatói közül többet megkeressünk felmerülő kérdéseinkkel, s velük egyeztetve kezdjünk hozzá az építkezéshez.

ISSN 2064-1966 (Print); ISSN 2631-0376 (Online) 
Legtöbbször az Árpád-kori települések kutatása során veremházak, más néven földbe mélyített házak kerülnek elő. A feltárások és a kevés történeti adat rámutat arra is, hogy a korszakban használtak más fajta épületeket is. Lakás céljára biztosan használják a korszakban a honfoglaló magyarság könnyen mozgatható sátrát, a jurtát, az épített lakóegységek közt pedig megtaláljuk a földfelszíni házakat, melyek a veremházhoz hasonlóan többféle technikával készülhettek.

A mi építkezésünk nem az egyetlen próbálkozás, a házrekonstrukció ötlete egyáltalán nem újdonság a régészet számára. Több veremház készült már régészek, de lelkes hagyományőrzők ötletei alapján is, mind rajzban, maketten és 1:1 méretben. ${ }^{1}$ A megvalósításhoz legfőképp Sabján Tibor kutatásait tudtuk használni, aki a teljes ház megépítésével és annak technikai kérdéseivel behatóbban foglalkozott.

Minden hallott vagy olvasott információt igyekeztünk felhasználni az építkezés alatt. Két utat láttunk kivitelezhetőnek: vagy kiválasztunk egy feltárt objektumot és annak a rekonstrukcióját készítjük el, vagy pedig megpróbálkozunk a lehető legtöbb régészeti közlést áttekinteni és egy - mondjuk úgy - „átlagos” Árpád-kori lakóobjektum régészeti adatokból ismert paraméterei alapján dolgozunk. ${ }^{2}$ Ez utóbbi mellett döntöttünk, mivel a szakirodalom elolvasása után egy változatos kép alakult ki bennünk, s szerettünk volna egy olyan lakóépületet elkészíteni, melyben megvalósíthatjuk az érdekesnek talált részleteket. Így egy kísérletezőbb jellegű építkezés mellett döntöttünk.

\section{A veremház megépítése}

A munkát ténylegesen 2011 februárjában kezdtük meg. Ekkor a kiválasztott területet pontosabban kijelöltük, és a kb. 20×20 méteres telket a helyben kitermelt akácfákkal körbekerítettük. Itt kell megjegyezni, hogy a fehér akác (Robinia pseudoacacia) Észak-Amerika őshonos növénye. Európába először Jean Robin hozta be 1620 körül. ${ }^{3}$ Az Árpád-korban tehát nem ismerték ezt a fafajt. Azonban úgy gondoltuk, hogy a 10-13. században is a helyben talált anyagokkal dolgoztak, így a helyben kitermelt fákkal dolgoztunk mi is.

A telek északkeleti oldalán árkot ástunk 50 centiméter mélységben, s a kitermelt földet a telek felé eső oldalon halmoztuk fel. Az árok elkészítése fontos volt, mert a területen egy állatállomány-védelmi program keretében lovakból álló kisebb ménest és racka juhokat tartanak, melyek állandó veszélyforrást jelentettek az építkezés fázisaira, valamint a később elkészülő házra is. A ménes így is többször, kisebb helyeken megrongálta a kerítést, amit folyamatosan újítanunk kellett. A kerítéshez a kivágott fákat lekérgeltük, kb. 120-140 centiméter hosszú rudakat készítettünk, majd végüket megégettük. Az égetés miatt a földben hosszabb ideig bírja a farúd, mivel egy égett kéreg képződik a fa belseje és a föld között, de a fa rostjai nem lesznek elzárva, mintha kívülről bekentük volna bármilyen anyaggal (például kátránnyal). Ezek után 50 centiméter távolságra egymástól a földbe ásott sekélyebb lyukakba ütöttük le azokat. Az így leszúrt karók lettek a kerítés „lécei”. A terület erdeinek jó része a Pilis Parkerdő Zrt. Ráckevei Erdészetéhez tartozik, mely 2538 Ha erdőt felügyel, 11 község határában kb. 90.000 Ha területen. ${ }^{4}$ Az erdészet Tököli Parkerdő néven tartja nyilván Szigethalom körzetét is. 2011. március 13-14-én a Parkerdő munkatársai rendelkezésünkre bocsátották az általuk kitermelt bálványfát ${ }^{5}$, melyet lelkes csapatunk a helyszínről gyüjtöttössze, és szállított el a kitermelést követő két napban. A növény kivágás után maximum 3-4 napig használható fel, mivel nagyon hamar elveszti ruganyosságát és szilánkosan törik. Így az első köteg szállítása után a készítők egy része a vesszők fonásához fogott. $A$ két nap alatt 7 ember részvételével elkészültünk a kerítéssel, csak a telek délnyugati és északkeleti végében hagytunk ki két 150 centiméter széles rést a kapuk számára.

A második napon a telek északkeleti végében kijelölt veremház gödrét is elkezdtük ásni, melyben a járószinttől kb. 70 centiméteres mélységig termeltük ki a földet. A gödör formája téglalap alakú, méretei $5 \times 3,2$ méter. A gödör délkeleti, hosszabb oldalára helyeztük a gádort.

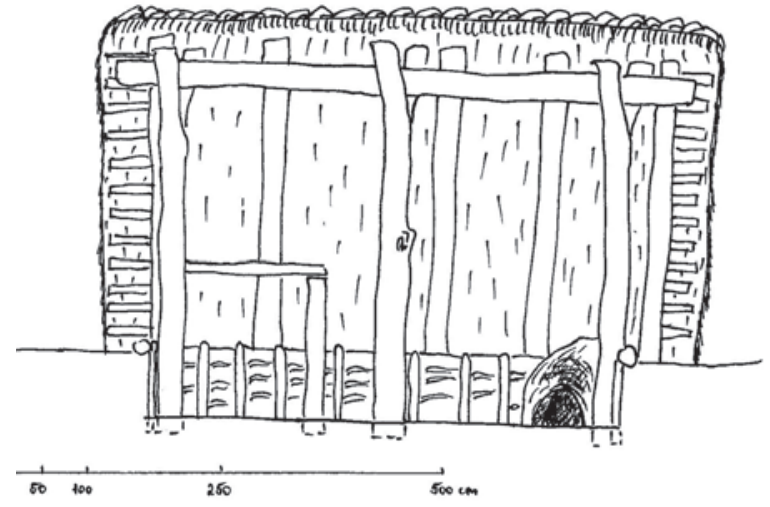

1. kép: A ház hosszmetszete

1 Takács 1999. 102.

2 Itt kell megköszönnünk dr. Takács Miklós és Petkes Zsolt közremüködését, akik a tervezés folyamán segítséget nyújtottak a tervező csapatnak és válaszoltak kérdéseinkre.

3 Engloner - Penksza - Szerdahelyi 2001. 103.

4 http://www.parkerdo.hu/rackevei_erdeszet 2012.11.10. 23:50

5 A bálványfa (Ailanthus altissima) az ecetfához hasonlóan nem őshonos növény Európában. A Szappanfavirágúak rendjébe, bálványfafélék családjába tartozik. Származási helye Kelet- Ázsia, ahonnan a 18. században került Európába. Gyorsan növő, gyökeréről több gyökérsarjat növeszt, így agresszívan terjeszkedő fajnak tartják. Engloner - Penksza - Szerdahelyi 2001. 108. 
A tetőszerkezetet az eddig elkészült házrekonstrukciókhoz hasonlóan a földön támasztottuk meg. Széleit Sabján Tibor elképzeléséhez hasonlóan nem a gödör peremén, hanem attól távolabb helyeztük el. ${ }^{6}$ Sátortetőt terveztünk a gödör fölé, melyet az eddig elkészült rekonstrukcióknál is használtak. A tető pontos méreteit nem ismerjük a házak döntő többségénél, az építőcsapat pedig az „ideális ház" építését választotta a kísérletezés lehetősége miatt, így a korábbi házaktól eltérően egy magasabb tetőszerkezetet képzeltünk el. A gödör mérete miatt a gyakran előforduló 3 tartóoszlopos elrendezést választottuk, mivel 4 méter szélesség fölött a terhelés olyan nagy lenne, hogy a szelemen valószínúleg hosszabb távon nem bírná a terhelést. Maga a gödör 4,8 illetve 5 méter széles, melynek középtengelyében helyezkedik el a három oszlop. A két szélső tartógerenda a gödör szélén ta-

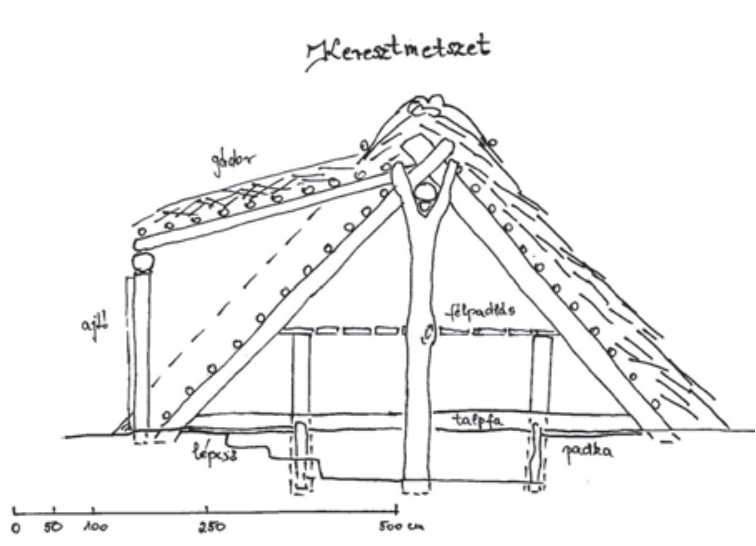

2. kép: A ház keresztmetszete lálható. Ezeken túl kell a szelemennek lógnia, így kb. 6 méter hosszú fát kellett keresnünk. A tartóoszlopok és a szelemenként használt fák átmérője 0,4-0,6 méter körül mozog, tehát nagyjából egyforma méretű törzseket választottunk a ház vázához. A tartóoszlopok végei mind villa alakúak, méretük 3,8 méter.

Ez utóbbi viszont új problémákat vetett fel, mivel az eddig elkészült épületeknél sokkal alacsonyabb oszlopokat használtak. Sabján Tibor egyik fontos hipotézise kifejezetten erre az „alacsonyabb” oszlop-szerkezetre épül: ha a gödör szélétől 1 méterre kihelyezzük a tető alját, a tető hajlásszögét pedig $45^{\circ}$ körül határozzuk meg, akkor a belső magasság 3,1 méter, a földfelszíntől számított magasság pedig 2,5 méter lesz. Emiatt Sabján szerint elképzelhető, hogy az oszlopokat előre kiásták és elhelyezték a gödrökben, majd ráemelték kézi erővel a szelement. A szelemenre támasztották a tetőgerendákat, és utólag ásták ki ház gödrét. Mint korábban is említettem nem volt célunk egy hipotézis mellett állni, vagy ellene érvelni, de a magasabb tetőszerkezet miatt mi egy másik utat választottunk.

Egy 2,5 méteres szelement is nehézkes kézi erővel felrakni, így lényegtelenné válik, hogy előre kiássuk a gödröt. Ráadásul a szelemen felhelyezését a gödör széléről is lehet irányítani, így nem válik fontossá, hogy utólag termeljük ki a ház gödréből a földet. Egy elég egyszerű, mondjuk úgy, „emelőszerkezetet" készítettünk, mely a következőkből állt: három, a tartóoszlopokkal egyforma magas fát (melyeket később a tetőszerkezethez használtunk föl) összekötöttünk a végüktől kb. egynegyednyi távolságra, majd felállítottuk azokat, így egy gúlát kaptunk. Az összekötött részen átvetettünk egy kötelet, melyet csigára tekertünk, végére pedig kampót kötöttünk. A három tartóoszlop helyét kiástuk: a munkafolyamat közben igyekeztünk függőlegesen fúrni, illetve ásni, hogy kevés visszatöltést kelljen az oszlopok mellé tölteni. Az oszlopokat a tetőszerkezethez kivágott gerendákkal támasztottuk meg, mivel azok közül is több villás felsőrésszel rendelkezik. Így a beállított oszlopok a ledöngölt föld mellett kaptak egy oldalirányú alátámasztást. Miközben a szelement ráhelyezzük, biztosan nem dől vagy mozdul ki egyik oszlop sem. A háromlábú emelőszerkezet, az öszszekötés után is magasabb volt a tartóoszlopoknál, mivel az oszlopok a földben álltak már kb 0,3-0,4 méter mélyen. Tehát a háromlábat arrébb helyezve át lehetett lépni az oszlopok fölött. A szelement áthurkoltuk a kötéllel, és ráemeltük az északi tartóosz-

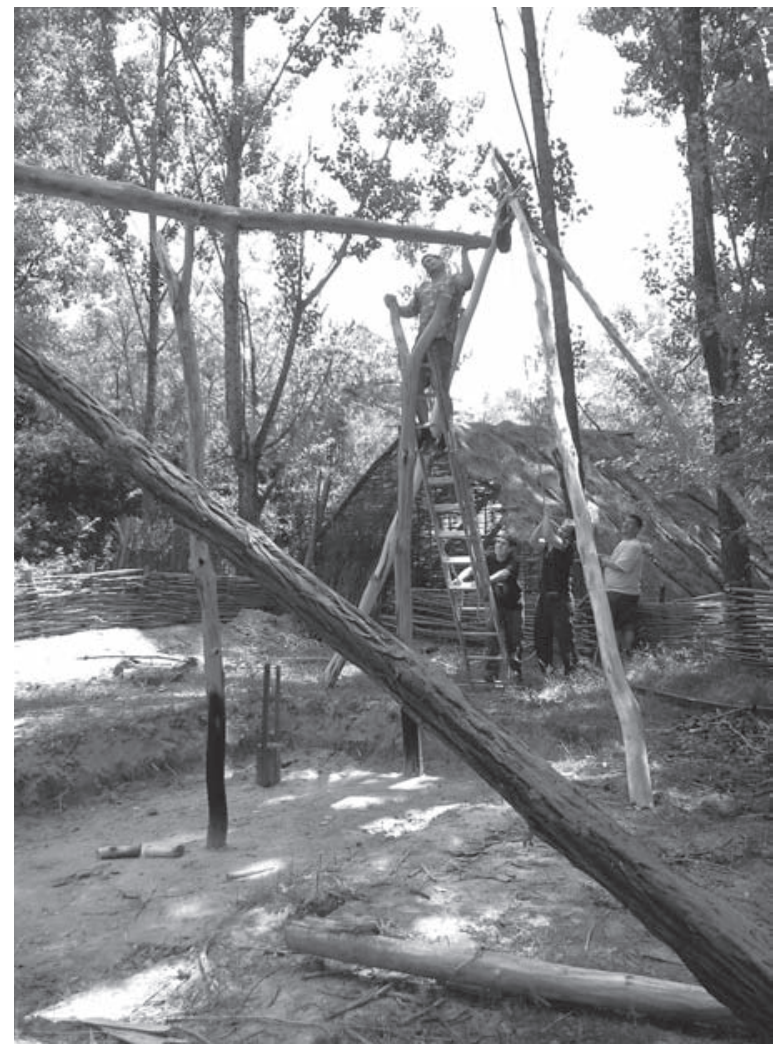

3. kép: A tetőszerkezet építése

6 Sabján 1999. 132. 
lopra, majd a háromlábbal „, hátra lépegetve” a gödör déli végéhez a kötelet a szelemen déli végére hurkolva a középső és déli tartóoszlopra emeltük. Itt fontossá vált, hogy az oszlopok tetejét megfelelő magasságúra vágjuk el, mert első emelésre a középső oszlop egyik ága túl magas volt, így a szelemen felhelyezésekor igazítanunk kellett rajta.

A ház mindkét oldalára 5-5 tartóoszlopot helyeztünk el. A ház déli oldalán a gádor miatt egy nagyobb hézagot hagytunk ki, hogy a bejáratot és a fonást később elkészíthessük. A gerendák alját mind megégettük, és körülbelül 10-20 centiméter mélyen a fölbe ástuk őket a gödör szélétől 140 centiméter távolságban. Mivel nem tudjuk a tetők pontos elhelyezkedését a gödörhöz képest, mi is Sabján Tibor elgondolásával értettünk egyet, miszerint a gödör falánál közvetlenül nem biztonságos elhelyezni a tető szélét, mert a gödör fala könnyen beomlana. Sabján a gödör szélétől 1 méteres távolságra helyezte a tetőt, a mi tetőnk viszont sokkal meredekebb lett volna így, mint a Sabján vagy a Szentgyörgyi Viktor-féle rekonstrukcióknál. Tehát nem azzal lett volna problémánk, hogy a lakók nem tudnak benne felállni, hanem épp egy túl magas és keskeny tető kaptunk volna. Ezért választottuk a 140 centiméteres távolságot a gödör szélétől, ráadásul így több helyet nyertünk a belső térben. Egy szerkezeti tényező még szempont volt a tető elhelyezésekor: az északi, kemencével átellenes oldalon terveztünk a belmagasság miatt egy félpadlást, vagy modern szóval "galériát". Ez teljesen hipotetikus elképzelésünk volt, viszont a régészeti adatok nem mondanak ellent, és ilyen tetőméretnél már érdemes átgondolni a tér kihasználásának akár egy ilyen módját is. Mivel a gödröt körben szintén befontuk majd betapasztottuk, felhasználtunk 4 karólyukat arra, hogy ne csak kisebb, 70 centiméter magas karót helyezzünk el benne, csak a gödör befonása miatt, hanem 170 centiméter magasak legyenek. Kettőt a sarkokban, kettőt pedig a középső tartóoszlophoz közel, a saroktól 150 centiméteres távolságra helyeztük el. Mind a 4 karó olyan magas, hogy érintkezzen a sátortető gerendáival, amelyhez odakötöztük a rudakat. A négy rúd tetejére pedig vékonyabb gerendákból és gyalult deszkából készítettünk egy tároló és alvó felületet. Felmenni a félpadlásra egy rönkből kialakított lépcsőn lehet, mely csak a félpadláshoz van rögzítve és a földre támaszkodik. A kialakításnál fontos volt, hogy olyan szerkezetet építsünk, mely a régészeti adatok alapján elkészíthető, tehát a járószinten nyomokat nem hagy. A szerkezet stabil, több ember és felszerelés súlyát elbírta, a tetőzetet nem módosította, illetve rongálta meg a terhelés után sem. Így mi, építők úgy gondoljuk ez egy kivitelezhető hipotézis lehet.

A tető lefedésére is több módszert láthattunk eddig a felépített házaknál. Sabján Tibor ${ }^{7}$ és Szentgyörgyi Viktor házánál ${ }^{8}$ a növényi eredetű fedőanyagra földet helyeztek el. Ez a szélesebb, kisebb tetőknél egy teljesen elképzelhető megoldás. Viszont a mi meredekebb és nagyobb felületű tetőnkön nem, vagy csak nehezen tudtuk volna leteríteni a földet. A gravitáció miatt a tető aljában sokkal több föld gyűlne föl, ami tovább foglalná a ház körül a helyet, az eső pedig egy idő után lemosná a földréteget a ház tetejéröl. Mi egy másik megoldást választottunk: a nádfedést. ${ }^{9}$ Mivel a terület a Dunához közel található, és célunk az volt, hogy a területen fellelhető anyagokból építkezzünk, mint ahogy tehették ezt a 11-13. században is. A nádat a tetőgerendákra merőleges irányú 11-12 darab rúdra helyeztük, melyeket korábban csapolással és kötözéssel rögzítettünk a gerendákhoz. A nád rögzítésének többféle módja van. Ma is az egyik leggyakoribb módszer a felvert nádas tető. Ennek elkészítéséhez átnéztünk több szakkönyvet, valamint megkerestünk a nádas szakmával még $\mathrm{ma}$ is foglalkozó szakembereket, akik tanácsokkal

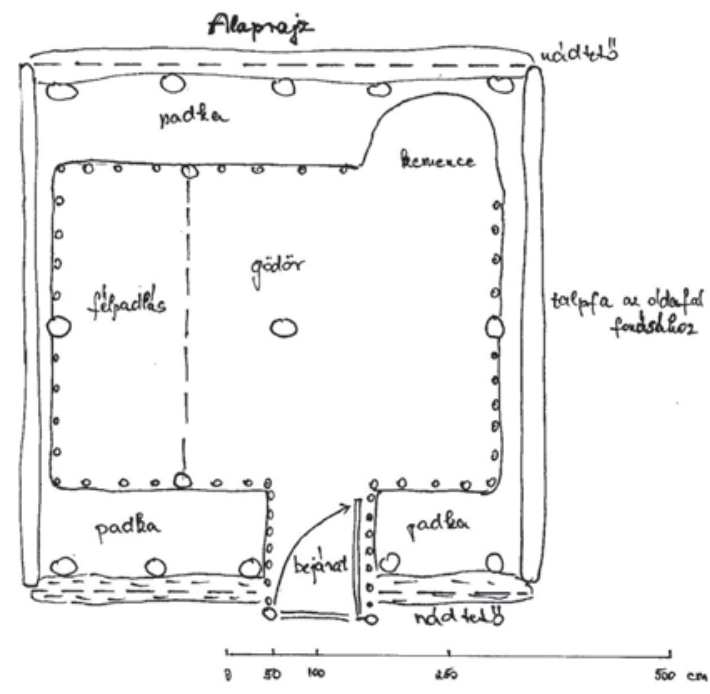

4. kép: A ház alaprajza láttak el minket. A gyakorlati tanácsok nagy segítségünkre voltak, mivel a nádtető-készítők több évtizedes tapasztalattal rendelkeznek és felhívták a figyelmünket apróbb részletekre is. A nádkévék felrakása után a kévéket az úgynevezett felverő fával ${ }^{10}$ kell felütögetni a helyükre. ${ }^{11}$ Belül a felütés után igazítani kell a kévéken, akár vágással is. A gerincen szintén többféle lezárás lehetséges, amiből mi az egyik legelterjedtebbet választottuk. A kévéket a felverés után nádtűvel levarrtuk, majd a legfelső kiálló kévevégeket a tengelyük körül elcsavartuk, úgy-

7 Sabján 1999. 132.

8 Szentgyörgyi 2001. 59.

9 Sabján 2007. 33.

10 A néprajzi anyagban többféle névváltozattal találkozhatunk, de jelentéstartalmukban a kifejezések megegyeznek (például „tetéjverő furkó”). Sabján 2007. 38.

11 Sabján 2007. 43. 
mond "megfontuk", és a végeket a tetőhöz rögzítettük mindkét oldalon egy-egy lekötözött farúddal. ${ }^{12} \mathrm{~A}$ tető körülbelül fél méter vastag, és sem hóban, sem esőben nem ázik be. A nádtetők akár 50-60 évet is kibírnak, de időnként újítani kell őket. ${ }^{13}$ Ilyenkor több nádréteget visznek fel, vastagítják a megkopott, tömörödött tetőzetet. Emiatt a tető jól fog szigetelni az elkövetkezendó években is, hiszen egyre vastagszik.

Az oldalfalakat és a gádor oldalait vesszőfonattal zártuk le. $\mathrm{A}$ fonás a bálványfa kitermelésével együtt másfél napig tartott. A ház két oldalán a szelemen alatt hagytunk egy kb. 10 centiméteres lyukat a füstelvezetés számára. Az összes fonást helyben kitermelt fehér agyaggal tapasztottuk be. Az agyagot kb. 50 méterre a háztól termelte ki az Őskultúra Alapítvány, mivel egy nagyobb tavat hoztak létre. Az innen származó agyagok közül a fehér színüből volt a legtöbb. A kiszáradt tömböket a telekre szállítottuk, ahol egy nagy fa dézsában vízzel hígítva és nád tetejéről levágott bojtokat és szárakat hozzáadagolva egy sürübb masszát kaptunk. Mivel a fal fonásához használt bálványfák 1-2 cen-

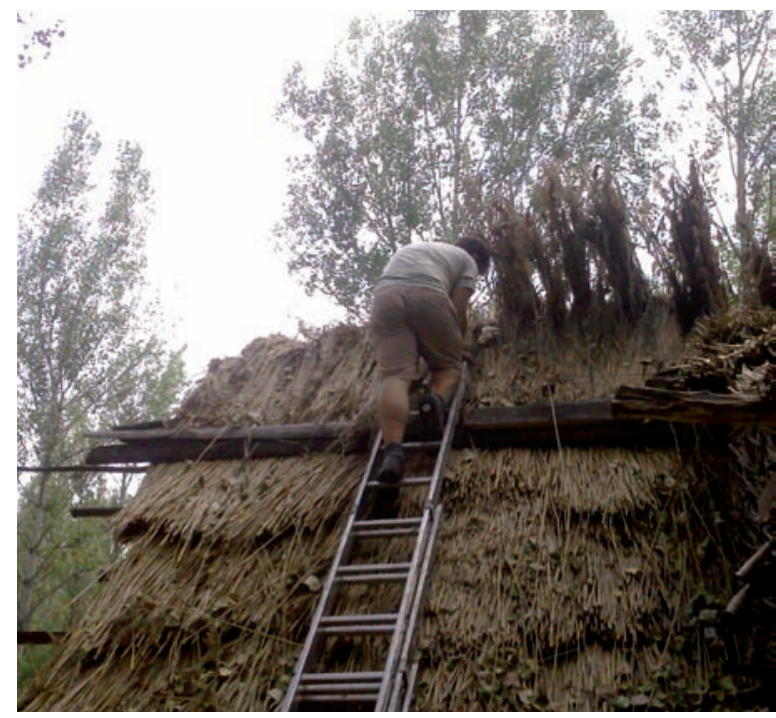

5. kép: A tető náddal való befedése timéter vastagok nagyobb hézagok lesznek köztük. Az agyaghoz kevert nádtörekkel egyenletes falat tudtunk létrehozni, áthidalva a hézagokat. A falakat kívül-belül be kell tapasztani. Mivel már aludtunk a házban, tapasztalatként elmondhatjuk, hogy a betapasztott fal nagyon jól szigetel. Az oldalfalakon mindkét oldalon egy-egy 30-30 centiméteres nyílást is készítettünk, melyekbe fa keretes ablakot helyeztünk. Az ablak egy fakeretre feszített bőrhártyából áll. Fényt ad a lakótérbe, télen pedig ronggyal vagy falappal eltömhető, ha túl hideg lenne.

\section{A kemence kérdése}

A kemence és a füstelvezetés megtervezése okozta talán a legnagyobb dilemmát a csapat számára. A lehető legtöbb feltárásról, valamint a lehetséges rekonstrukcióról szóló publikációt igyekeztünk összegyűjteni. Ezen kívül próbáltuk megkeresni azokat, akik szintén álltak már a probléma megoldása előtt. A füst akadály nélkül a lakótérbe vezetéséről a magam részéről fenntartásaim voltak, a megbeszélések után az építőcsapat többi tagja is ezen a véleményen volt. A témához kapcsolt néprajzi párhuzamok elolvasása után sem véltük úgy, hogy ez egy jó megoldás lenne. Gyakorinak találtam, hogy olyan verem-, illetve gödörházakat említenek párhuzamként, melyek vagy átmeneti szállásokként funkcionáltak pásztorok számára vagy pedig valóban mélyített házak voltak, de a belső elosztásuk már a többosztatú épületekhez kapcsolták őket. ${ }^{14}$ Ez utóbbiaknak többször már külön konyhájuk és kéményük is volt. A mi házunk azonban egyterủ. Számunkra az tünt a legvalószínübbnek, hogy a néprajzi adatokhoz hasonlóan többféle megoldás létezett a füstelvezetésre is az Árpád-kor folyamán, ahogy többféle kemencekészítési megoldást is találunk. A tüzelőberendezést választottuk ki először: az agyagból tapasztott kemence mellett döntöttünk. Kovács Eszter tanácsára egy 1999-es Csepel-Nyilasokra-dúlőn talált ház kemencéjét szeret-

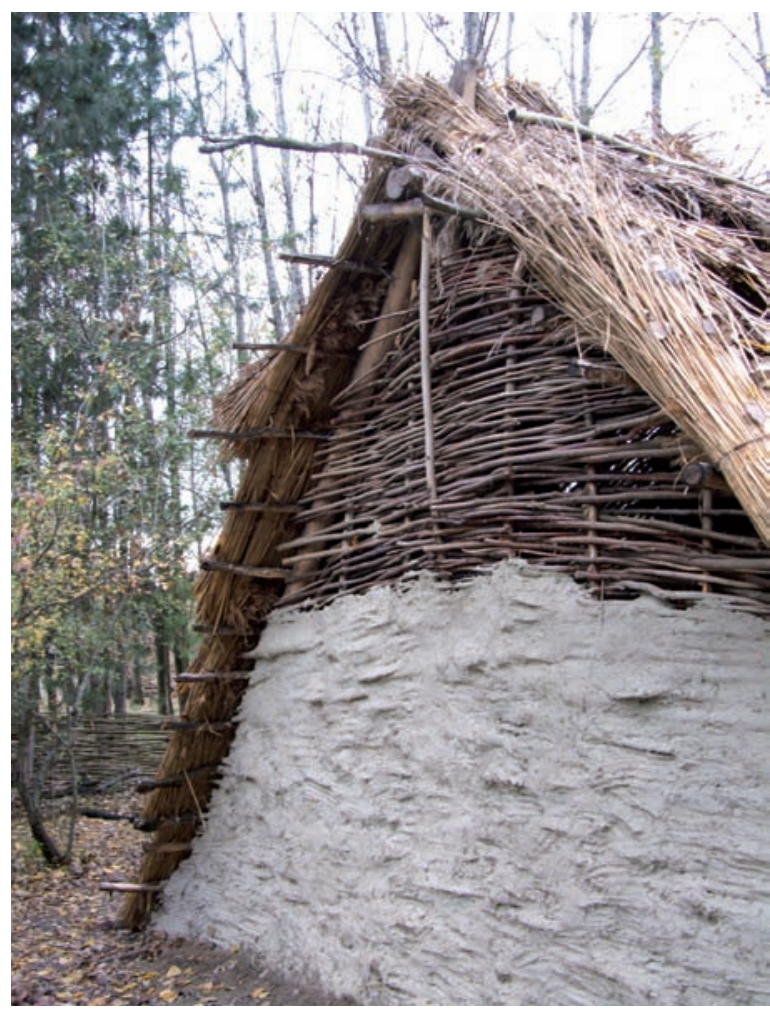

6. kép: Az oldalfal tapasztása

12 Sabján 2007. 43.

13 Sabján 2007.45.

14 Dám 1990. 133. 
nénk felépíteni. ${ }^{15}$ Választásunk azért esett erre a kemencére, mert a kemence teteje nem domború, hanem egy törést láthatunk a tetején, ami egy kerek lyukat formáz. A kemence tetején kialakított nyílás, ahol a füst távozhat egy elfogadhatóbb füstelvezetési módszer számunkra, mint a szájon át távozó füst. A gondolatmenetünk az volt, hogy bár a füstös konyhákban is gyakran találunk olyan kemencéket, melyek száján át távozik a füst, de ott mégsem a padló közelében található a kemence, amihez nem csak lehajolni, hanem letérdelni, odakuporodni kellene a kemence szájához, egyenesen a kiáramló füst közepébe. Ráadásul a szabadkéményes konyha nem a lakótérbe füstöl, hanem egy jól megépített kürtőbe, ami eleve szívja a füstöt felfelé, így szabad a légáramlás. Ezen kívül a ház tervezésénél figyelembe kell vennünk, hogy a füst bárhol is távozzon (a kemence száján, tetején vagy netán egy kürtőn keresztül) a tető anyaga miatt fokozottan kell figyelni a tűzveszélyre. Ez természetesen problémát okozott minden korszakban. Tudjuk, hogy igen hamar felgyulladt a többosztatú házak padlása is. Emiatt gyakran a tetőzetet belülről betapasztják agyaggal. ${ }^{16}$ A tűzbiztonság miatt feltételeznünk kell valamiféle tűzfogót, szikrafogó építményt a házon belül (ami nem zárja ki, hogy a tetőzetet is betapasztották a biztonság kedvéért a szikrafogó mellett). ${ }^{17}$ Nem említettem egy problémakört, ami a füstelvezetés kapcsán szintén felmerült: ezek a nyeles házak. Felmerült a nyél megépítésének gondolata is a tervezés során. Több dolog miatt vetettük el egy nyél elkészítését: egyrészt mert a ház egy teljesen sík, erdős területen áll, állandó uralkodó szélirány nincs. A füstelvezetést mi inkább a természetes áramláshoz szeretnénk igazítani. Mivel a füst felfelé száll a hőmérséklete miatt, egyszerűbb megoldásnak tartjuk a vertikális elvezető megoldásokat, mint egy kürtőt. Ezt az is indokolja, hogy a kemence használata során a kürtő és a kemence szája között kellene dolgozni a fözés során, pont a füst áramlásának vonalában, ami mindenképpen megnehezítené a munkát.

A fentiekben vázolt kép jelenleg egy hipotézisünk, melynek munkafolyamatáról és használati tapasztalatairól a tavasz folyamán tudunk beszámolni. Viszont a tervezési folyamat bemutatása miatt mindenképpen fontosnak tartottam a kemence és a füstelvezetés megemlítését.

\section{Eredményeink}

Az építkezéshez amennyire megoldható volt, igyekeztünk kézi erőt használni. Természetesen, amikor 100-150 méternél nagyobb távolságról hoztuk a kitermelt alapanyagokat használtunk gépjárművet. Ezen túl az volt a meglátásunk, hogy ha nem tudjuk a kézi eszközöket felhasználni, akkor olyan elektronikus szerszámot vegyünk igénybe, amely technikailag ugyanazt a műveletet végzi el, a felületet nem alakítja át a kézi megmunkáláshoz képest. Tehát a kézi fúró mellett használtunk elektromosat, illetve a kézi fürész mellett, ha

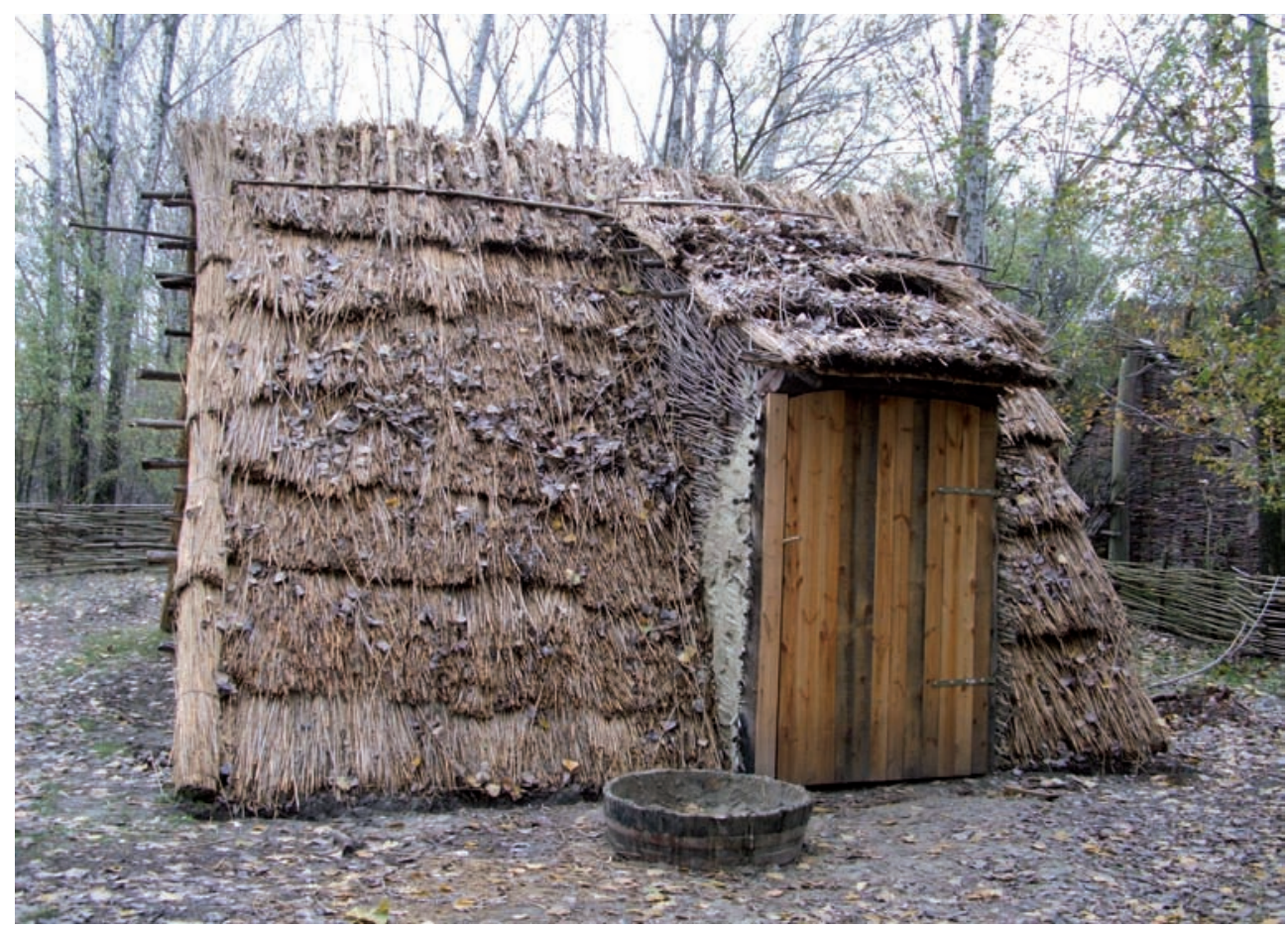

7. kép: A rekonstruált ház

15 Kovács 2001. 438.

16 Dám 1990. 134

17 Istvánffy 2011. 224. 
nagyon kevesen tudtunk dolgozni (2-3 fős létszámnál) benzinmotoros láncfürészt is. Véleményünk szerint ez nagy mértékben nem befolyásolja a munka menetét. Döntő többségben kézi erővel hajtottuk végre a munkafolyamatokat, így a fák kérgelését, megégetését, elhelyezését, a nád felhelyezését, kötözését, a falak befonását és a tapasztást is.

Az általunk kitermelt anyagokkal készült az épület, a szerszámok közt találunk olyat, amit nem mi készítettünk (ilyen a fürész, balta, a fúró vagy a létra). Ezek egy részét szakembertől kellett a korabeli embernek is vásárolni. A vásárolt eszközök mellett az egyszerúbb szerszámokat magunk készítettünk el például a nádfelverő fát vagy a padló és föld tömörítéséhez egy döngölő rönköt. Tehát az összegzésnél bele kell számítanunk azokat a munkaórákat, melyeket a kitermelésre, anyag-előkészítésre illetve a szerszámkészítésre szántunk. Ezek tükrében összeszámolva a munkaórákat, arra a következtetésre jutottunk, hogy mi körülbelül 3 hetet töltöttünk el az építkezéssel átlagosan 4-6 ember munkájával. Következtetésünk azt volt, hogy egy nagyobb család, vagy faluközösség 1,5-2 hét alatt megszakítások nélkül, teljesen lakható épületet tudott felépíteni az Árpád-korban. Így teljes mértékben egyet tudunk érteni Sabján Tibor hasonló következtetésével, a saját tapasztalataink alapján..$^{18}$

A házunk teljes mérete $33,5 \mathrm{~m}^{2}$, ha a galériát is hozzávesszük, akkor 36,9 m²-t kapunk. Úgy gondolom, egy ilyen méretű házban már valóban elfér egy család, több gyerekkel, valamint az ingóságaikkal együtt. A padkák elég nagyok ahhoz, hogy ülésre és alvásra is lehessen használni őket, emellett tárolásra is alkalmasak. Gyalult deszkával fedtük le padkák tetejét, a gödör oldalát pedig a régészeti adatok alapján fontuk és tapasztottuk, hogy ne omoljanak be a terheléstöl. A padkák így nehezebb tárgyak elhelyezésére is alkalmasak.

Hozzá kell tennem, hogy a munkánkat egyáltalán nem tekintjük lezártnak, mivel a ház használatra készült. Az építési munkafolyamatot lezártuk, de a belső tér felhasználását, esetleg díszítését ${ }^{19}$ még az idei év folyamán fogjuk befejezni. Mivel kézmüvesek is vannak közöttünk így tervezzük a telek és a ház felhasználását ilyen téren is. Itt kifejezetten egyik ötvös és kovács végzettségú tagunkra gondoltunk, illetve jelen dolgozat írója a textilfeldolgozás és készités korai módszereit szeretné vizsgálni. Így az ezekhez szükséges eszközök és objektumok elkészitését is célul tűztük ki. Szeretnénk külső kemencét és szövőeszközöket is készíteni, illetve használni a házban és a ház körül.

\section{Köszönetnyilvánítás}

A munka állandó résztvevői (Ádámffy Zsigmond, Lengyel Gábor József, Lőrincz András, Dittera Károly, Kálmándi Gyula és Zay Orsolya) szeretnék kifejezni hálájukat a Mare Temporis Történelmi Hagyományokért Alapítvány, az Őskultúra Alapítvány és minden kedves Barátunk és Ismerősünk felé, valamint az összes kutatónak, akik idejüket és energiájukat rászánták arra, hogy kérdéseinkre válaszoljanak, illetve részt vegyenek a ház felépítésében. Az építők minden kedves érdeklődőt szeretettel várnak az elkészült házhoz, az év bármely szakában.

\section{Összefoglalás}

Több külföldi régészeti parkban, történeti emlékhelyen volt baráti társaságunk, a Mare Temporis Történelmi Hagyományokért Alapítvány tagjai az elmúlt években, ahol életmód-bemutatókat, kísérleti régészeti kutatásokat láttunk. Ezek alatt fogalmazódott meg bennünk a gondolat, hogy készítsünk egy épületet, s 2010 őszén hozzákezdtünk az adatgyűjtéshez és az előkészületekhez. Az alapgondolat az volt, hogy egy olyan házat akarunk építeni, amely a régészeti forrásoknak, a kevés rendelkezésre álló történeti adatnak és a néprajzi párhuzamoknak is megfelel, de mindenképpen lakható, mivel az építőcsapat tagjai hosszabbrövidebb idő eltöltését tervezik a házban, mind a négy évszakban, annak elkészülte után. İgy lett igazán kísérleti jellegú a házépítés, mivel a régészeti nyomok után elképzelt ötleteket, rekonstrukciókat próbáltuk meg kivitelezni 1:1 méretben. Eddig már több ház épült, melyet cikk vagy tanulmány formájában közöltek, így összegyűjtöttük a közléseket, felkerestünk több, a korszakkal foglalkozó szakembert, hogy minél több ötletet gyújthessünk a megvalósításhoz. A választott periódus az Árpád-kor lett, s az ott talált objektumok közül a félig földbe mélyített vagy veremházként is ismert háztípust választottuk. Célunk nem egy eddig ismert módszer bizonyítása vagy cáfolása volt, hanem a saját elgondolásaink kivitelezése. Ennek eredménye az lett, hogy vannak hasonló, de eltérő részek is az építkezésben a korábbi megoldásokhoz képest. A lehető legtöbb részletet szerettük volna megörökíteni, így az építésről részletes fotódokumentáció készült, amit később napló formájában le is jegyeztünk. Az elkészült épület egy elméleti rekonstrukció lett, mely a régészeti adatokat nem módosítja, de az eddigiekhez képest egy újfajta elképzelést mutat be, mely szintén kivitelezhető a korabeli technikai felkészültséggel.

18 Sabján 1999.145

19 Mivel a területen a fehér felhasznált agyagon kívül vörös és sárgás is található, tervezünk a tapasztott felületeken festést ezek felhasználásával. Ugyan ilyenre egyáltalán nincsen régészeti bizonyítékunk, de egy rekonstrukcióban úgy gondoltuk, megfelelő lehet. 


\title{
A reconstruction of a pit-dwelling from the era of the Arpad Dynasty
}

\author{
ORSOLYA ZAY
}

In 2010 a group of historical reenactors, the members of the Mare Temporis Foundation for Historical Traditions, decided to build a house-reconstruction in Hungary from the 11th-13th centuries. We took part some festivals in Europe where we saw high quality experimental archeology. The researchers and reenanctors dressed up in period clothes, showed the way of life and made the arts and crafts to the tourists. We determined to build one type of house from Árpádian period. We chose a Historical Park in Hungary and got a place from the Foundation of the Park where we started the building procession. Informations from archeological and ethnographical articles and monographies were collected. After that we searched people -both archeologists and reeanctors - who have experiences in the reconstruction process. When we collected the informations about the original dwelling-houses we planned our building. During our work we made written notes and took photos about every different building session. We have civil jobs so thus we worked only in weekends, so that we finished the building procession in 2012. We didn't want to exactly follow or contradict to anybody's hipothesis, only made our idea but that was important to insist on archeological remains. In conclusion we can present a real pit-house reconstruction, which can be used as a dwelling. The total measure is $36,9 \mathrm{~m}^{2}$ with the area of our loft in the north end of the house. You can use the berm to sit and sleep next to storage fuction. In our opinion this house is quite good for a bigger family and their properties. Moreover this family or residents of a little village were able to build a house like ours during 1,5-2 weeks. The house came through remarkably well the autumn and winter. The walls and the roof from reed don't leak the water, and the house is dry all year. The builder group welcome everybody who enquires the pit-dwelling from spring to winter.

\section{Irodalom}

Dám L. 1990.: Földbe mélyített lakóépítmények az Alföld népi építészetében. Jósa András Múzeum Évkönyve 33-35. 133-152.

Engloner A. - Penksza K. - Szerdahelyi T. 2001.: A hajtásos növények ismerete. Budapest

Istvánffy Gy. 2011.: Öskor. Népi Építészet. Az építészet története. Budapest

Kovács E. 2001.: Földbe vájt kemencéjű veremház feltárása Csepel - Nyilasokra dűlőn. In.: Cseri Miklós - Füzes Endre (Szerk.): Ház és ember. A Szabadtéri Néprajzi Múzeum Évkönyve 14. 437-446.

Sabján T. 1999.: A veremház rekonstrukciója. In.: Bencze Zoltán - Gyulai Ferenc - Sabján Tibor - Takács Miklós: Egy Árpádkori veremház feltárása és rekonstrukciója. Monumenta Historica Budapestinensia 10. 132-176.

Sabján T. 2007.: Tetőfedések. Budapest

Szentgyörgyi V. 2001.: „Földbeásott lakóház”. In.: Cseri Miklós - Füzes Endre (Szerk.): Ház és ember. A Szabadtéri Néprajzi Múzeum Évkönyve 14. 55-100.

Takács M. 1999.: Lakóház-rekonstrukciók az Árpád-kori telepkutatásban. In.: Bencze Zoltán - Gyulai Ferenc - Sabján Tibor -Takács Miklós: Egy Árpád-kori veremház feltárása és rekonstrukciója. Monumenta Historica Budapestinensia 10. 93-129. 